\title{
Re-locating memories: transnational and local narratives of Indian South Africans in Cape Town
}

\author{
Uma Dhupelia-Mesthrie
}

\begin{abstract}
This article plays on the word re-location to examine the memories of Indians in South Africa through oral histories about relocation as a result of the Group Areas Act, to memories of parents and grandparents relocating to South Africa from India as told to interviewees and to their own memories of journeys to India and back. The narratives of mobilities traverse time and national boundaries and are counter-posed by narratives of local mobilities as well as stasis. The article identifies ways of narrating, themes of narration and the meaning of memories while noting the re-location of memory construction against the backdrop of South Africa's democratic transition and the 150th commemoration of the arrival of indentured Indians to South Africa. It argues that the local and the national are important in narrations of transnational journeys, thus advancing a particular approach to transnational memory studies.
\end{abstract}

\section{Introduction}

In 2010 the Kalusta Karjiker Education Society (KKES) in Cape Town held a glittering banquet to mark its 8oth anniversary and the hall foyer was dominated by an image of Kalusta village in India located within Ratnagiri District. There were many side panels with photographs of families, past and present, from Kalusta. A magazine commemorating the transnational links between Muslims in Cape Town and Kalusta was given to each attendee. ${ }^{1}$ Its pages evoke the beauty of Kalusta through which the Washishti River flows and, mindful of the South African context, likens Kalusta to the scenic Knysna region in the Western Cape, which is blessed with forests, lakes and lagoons. The compilers devoted space to the memories of early migrants but also highlighted sites of significance in Kalusta, such as the Panona Primary School built by the flow of money from Cape Town migrants in the 1930 s and the Haji Dawood Amien High School built in 1959 by Dawood Amien, one of the early Kaluskar migrants in Cape Town. Visual images celebrate the early migrants but also the generations born in Cape Town who gather annually for a Kalusta family fun day. The ships, SS Kampala and SS Karanja, secured some space, for they have come to acquire significance in the memories of Cape Town Indians as these ships linked their passengers to India and South Africa in their journeys across the Indian Ocean. 
There are many such occasions in Cape Town whereby transnational linkages are commemorated and celebrated by Muslim Indians who originally came from the Konkan areas of Maharashtra, and, who make up the largest sector of the Indian population of Cape Town. In 2011 Asians (mostly Indian) in the Cape Town metropolitan area numbered 51,786 out of the city's total population of 3,740,026, making up just $1.4 \%$ of the city's population. 2011 (Statistics South Africa, Census, 2011: 2 ). While scholars have commented on the way in which Muslim Indians are increasingly linking themselves and their religious and social practices to the Arab world rather than South Asia (Hansen, 2012: 23), the practices of Muslim Indians in Cape Town show how India continues to have salience. In 2010, for instance, a Super 8 Cricket tournament was inaugurated, whereby third and fourth generation Indian South Africans constituted teams invoking the villages of the Konkan: Sangameshewar; Latvan; Kalusta; Karji; Morba; Khed; Sakhrol; and Habsani Royals (of Janjira). The idea behind the cricket tournament was 'an opportunity to bring people of a common grouping and culture towards a platform of association and acknowledgement of identity. The intention was to galvanise them with their familial heritage and value systems,' 2 and it was described as a 'celebratory' cultural event. 3 Such 'village gatherings' are rare amongst Gujarati Hindus who constitute a minority within the Indian population in Cape Town and whose numbers from individual villages are not conducive to such gatherings. The 2011 census did not count religious groups, but according to the 2001 census Hindus made up $0.2 \%$ of the city's population; Gujarati Hindus are the largest group, followed by Tamils (Directorate of Strategic Information, 2003: 7, 9 and 15 ).The family picnic organised by Gujarati Hindus who originate from Billimoria is an isolated event.4

One of the biggest transnational projects in Cape Town has been funded by Abdulla Gangraker whose father came in the early years of the twentieth century from Morba. Gangraker constructed a school for young girls and a clinic in Morba as major acts of remembering. As he indicates:

When I come to Morba I want ... to try to do whatever I can do for the people of the village ... so that they can remember there was a person like my father that was born here who left this village for South Africa for the purpose of better living for these people in this village.5

He has also funded a film project documenting the links between Cape Town and the Konkan villages and highlighting the biographies of Cape Town residents from these villages.

Journeys to India by Indians in Cape Town also fall in the category of what Sabine Marschall has called 'personal memory tourism' or 'roots tourism'. These involve visits to sites of personal or familial significance (Marschall, 2014). Majid Mowzer (b. 1953), Chairperson of the Cape Town Janjira Habsani Society and a third generation South African, first visited India in 1969 but in 2007 he took his own children to his village, Aravi in District Raigad. Since that trip his daughter has been three times. Such trips involve remembering - remembering a father and his efforts to construct a house in the village and 
his life of 'sacrifice' (author's interview with Majid Mowzer, 20 December 2009). The Habsani Royals cricket team also travelled to India and played matches in Mumbai and the villages of Aravi and Walwat. ${ }^{6}$ The name Habsani echoes the time, when, from the fifteenth century onwards Abyssinian slave elites began dominating the Konkan coast and the Habshis or Siddis ruled over the princely state of Janjira (Oka and Kusimba, 2008: 203-217). This significance of a time of African dominance in this part of India is not all that apparent to the current generation of Muslim Indians in Cape Town. What is important is their links as South Africans to India and the personal connections to their villages in Janjira.

The physical landscape of Cape Town also bears memories of India. Janjira is remembered in the names of several shops in Cape Town. The Gandhi Memorial School, a vernacular school established by Gujarati Hindus in 1949 also celebrates the links with Gandhi, a figure of transnational significance linking these two countries. A quiet street of Cape Town, in the former Indian group area of Rylands, bears the name Bodali. This was an act of remembrance initiated by a private developer, Chiba Jeram Patel, who came from the village of Bodali as a teenager to join his father in Cape Town in 1926. For Chiba's son Kanti (b. 1953), Bodali is about poverty and he invokes the example of Khayelitsha in Cape Town, one of Cape Town's largest but poorest townships for black Africans (author's interview with Kanti Patel, 13 January 2010); the naming of a street after Bodali stands as a story of progress - a story of mobility from poverty to wealth.

Transnational links have always had some significance as seen in the early naming of sites and the birth of village societies. However, these links, and commemorations of them have increased in the post-apartheid era. These partly reflect the current affluence of Indian elites but, mainly, the influence of the idea of the rainbow nation which marked the birth of the democratic era and provided the freedom to explore roots and heritage.

This article while drawing preliminary attention to the importance of transnational links and the acts of memory-making in public sites and in print which signal their importance, shifts focus to a discussion of transnational memories as produced in a dialogue between researcher and interviewees. The interviews focus on journeys from India to South Africa and from South Africa to India by Indian South Africans. The article, however, also asks what happens when we consider stories (memories) of transnational journeys to stories (memories) of local journeys. The central argument is against isolating transnational memories from those memories of journeys within the nation and journeys within the city whether voluntary or forced (because of the Group Areas Act). While it is obvious in its attention to India-South Africa linkages, it seeks in the main to advance an approach to transnational memory studies.

\section{Theoretical and Methodological Considerations}

South African oral history work was stimulated in the 1970 s and 1980 os by social historians to produce knowledge about the urban and rural lives of the black population of South Africa (Bickford-Smith et al., 2001: 5-21). In Cape Town, one of the major subjects of oral history work has been forced removals though, more recently, there have been attempts to expand 
the subject matter to include culture, sport, work and trauma and violence (Field, 2001; Field, 2012; Field et al., 2007 ). One of the most significant shifts in South African scholarship has been the emphasis on memory production in museums and heritage sites as part of conservation management (Julius, 2008; Layne and Rassool, 2001; Lusaka, 2015). As Murray and Witz put it, their focus is on how the 'exhibitionary imperative' drives memory production and transforms it (Murray and Witz, 2014: 117-147). Newer work also explores the mnemonic value of the family photograph album for memory production (O'Connell, 2012). Despite significant shifts, most oral history work falls within what Astrid Erll has called the 'container culture', focussed as they are on the national (Erll, 2011: 7) and several works specifically reflect the importance of Pierre Nora's sites of memory approach which is nation bound (Field, 2012: 101-116; Lusaka, 2015).

Since the 1990s, oral histories of the liberation struggle have also been undertaken and there are a vast number of memoirs, autobiographies and biographies of key struggle figures who lived lives of exile (South African Democracy Education Trust, 2015 ).7 A small beginning has been made to analyse these transnational memories and their relevance for identity formation (Dhupelia-Mesthrie, 2012). The transnational figure of the migrant labourer tramping across borders to enable the mining economy of the country built on cheap labour looms large and there is potential in oral histories of these border crossings (Likuwa, 2012). There have been some transnational memory-works involving refugees and new migrants from other parts of Africa in South Africa (Field, 2012; Gunn, 2011; Masada, 2007; Smit and Ragunan, 2015). They highlight issues of trauma and memory and shed light on identity and meanings of home. Marschall's work on transnational tourism constitutes a significant foray in the field of transnational memories (Marschall, 2014).

Globally, there has been growing 'stirrings' in scholarship on transnational memories. As De Cesari and Rigney have argued 'the time is ripe to move memory studies ... beyond methodological nationalism ... national frames are no longer the self-evident ones they used to be in daily life and identity formation' (De Cesari and Rigney, 2014: 2). While there has been a significant transnational turn in the writing of the history of Indian South Africans with recent histories being located within Indian Ocean Studies, or as connected histories between India and South Africa, which point to transnational networks and links (Gupta et al., 2010; Hofmeyr and Williams, 2011), there is potential to expand the discussion by drawing on transnational memories (Dhupelia-Mesthrie, 2012; Dhupelia-Mesthrie, 2014; Hiralal, 2013).

Vertovec has argued for a need to consider what transnationalism means not only to the original migrants but to second and later generations (Vertovec, 2001: 576). This article draws on interviews with four Gujarati Hindus and highlights transnational memories of second and third generation Indians. Natver Patel (b. 1933) was born in India but came to Cape Town as a six year old with his parents and sibling - his father was the first to come to South Africa some decades earlier (author's interview with Natver Patel, 16 January 2010); brothers Bhadra Jaga (b. 1937) and Gunwant Jaga (b. 1942) are third generation South Africans and were interviewed jointly (author's interview with Bhadra Jaga and

\section{http://repository.uwc.ac.za}


Gunwant Jaga, 17 April 2010); Damyanti Patel (b. 1954) is a third generation South African (author's interview with Damyanti Patel, 20 June 2009). Oral historians have critiqued the empiricism inherent in many oral history projects and have urged (drawing on the work of European scholars, for example, Alessandro Portelli) to consider the nature of memory (Field, 2012: 3ff). Social historians have also come under some critique for ignoring how interviewees tell their life stories (thus ignoring narrative structure) and for not interrogating knowledge production in the interview context (Minkley and Rassool, 1998: 96ff).

This article thus pays attention to how stories are narrated, how memories are produced in the course of an interview, what emerges voluntarily and what emerges from questioning, and finally, what is the importance of the local and national in the telling of the transnational. The selection of a few stories allows for more in-depth analysis. Memory production took place against the back- drop of the 2010 commemoration of the 150th year of the arrival of indentured Indians to Kwa-Zulu Natal. It was enthusiastically commemorated nationwide though not without some critical reflections (Maharaj, 2012) and, in Cape Town, there were a series of public lectures and a banquet dinner (Mesthrie, 2011). While Cape Town did not receive indentured labour and it has a very small population of Tamils who are the descendants of indentured labourers who came to the Cape following indenture, Indian Muslims and Gujaratis in the city were stimulated to probe their roots and heritage.

This idea of considering local, national and transnational journeys without prioritising one over the other has support in newer mobility studies. Ben Rogaly has recently argued that emphasising 'cross-border moves and networks in people's lives' leads to 'a scaler hierarchy in which long-distance and international moves of residence are by implication considered more significant than short-distance ones or moves within national borders'. He argues that 'there is no necessary hierarchy in people's experience of spatial mobility; a short distance move or a set of everyday mobilities might be remembered as just as meaningful to an individual as an international move'. He simultaneously urges an 'attention to fixity' (Rogaly, 2015: 540-541). This study thus recognises that there are also periods of stability and lack of movement across spaces (for example, fixity of residence).

Michael Rothberg has argued that 'the transnational turn cannot simply leave behind national memory if it is to offer a new approach'. He argues for the need to pay attention to the 'different layers of memory ... and different scales of memory (local, national, transnational, etc.) without subordinating one to the other' (Rothberg, 2014: 127). De Cesari and Rigney remind us that 'the term transnational itself crucially serves as a reminder of the fact that even in a so-called post-national age "the national" as a framework for identity and memory-making is still a powerful one'. They point to a 'deep entanglement between the national and the transnational' (De Cesari and Rigney, 2014: 6-7). This article explores this 'deep entanglement'. 


\section{Remembering so that 'the people see what the people went through'}

Natver Patel (b. 1933) was 77 years old when I interviewed him at his home in Rondebosch East (author's interview with Natver Patel, 16 January 2010). He had heard that I was working on a history of Indians in the city and telephoned me. That he took this initiative indicated to me that he had a story he wanted to tell. For most of my other interviews I have often had to convince people why their stories are important to tell. Natver was born in Haldharu, Gujarat - the village of his mother. His father was an absent figure. In fact, Natver grew up without knowing his father for the first five years of his life. His father worked in Cape Town, South Africa and returned in 1937 to India for a few years, as was the customary practice of most first generation migrants. Natver, his infant brother, and parents then journeyed to Cape Town in 1939.

Natver's unfolding narrative that afternoon was all about journeys: his father's first journey to Cape Town in the early 1900 (as told to him by his father); his own journey in 1939; his high school days which involved travelling by train for one and a half hours from the Strand to Cape Town ('I spent four years on a train'); his journey to India between 1951 and 1953 to study; his return in 1953; the 'start of the bad group areas' which led to the loss of the lease on the shop in the Strand in 1956; and his move to Simonstown. There were some years of fixity in terms of residence in the Strand from 1939 to 1951 and then another 49 years of stability in Simonstown where they lived above their shop. There were local journeys to Cape Town's market in Epping and stops along many of Cape Town's suburbs for, in addition to the shop, he operated a wholesale business in fruit and vegetables. His father's journey is marked by economic mobility. From hawking vegetables in the city on his arrival in the 1900 carrying a basket, his father graduated as did many hawkers to using a pushcart before opening his own shop in Hanover Street, District Six. His father later moved to Claremont and, finally, to the Strand where his life journey ended in 1953.

The story told to me by Natver in his lounge was told to him by his father on their local journeys by car between Strand and the school in Cape Town city centre. While most times he travelled by train, Natver had learnt to drive a car and his father could not. If the driver did not turn up and his father needed to go to the Cape Town market, Natver would drive his father in the morning and then after school the two would return to the Strand; 'And on the way there were no car radios at the time so he used to talk and he used to tell about this - all his stories.' Natver's own visit to India in 1951-1953 provided an opportunity to examine a family box of photographs and documents and in that box he found some confirmation for his father's stories about India and his journeys.

From Natver's telling of the India his father left behind, India is seen as place of poverty and also of plague. His father's entire family died in a plague and he was brought up by an uncle. Of significance to this article, is how Natver relates the story of how and why his father came to South Africa and then his own life story of how he avoided being forced to move from Simonstown to Rylands as a result of the Group Areas Act of 1950 which demarcated racialised spaces for residence and business. There are similarities in the telling of the journey of relocation from India and a story of avoiding relocation to Rylands to secure

\section{http://repository.uwc.ac.za}


stability of residence and business. The two stories gain significance when placed together. They speak of agency in the face of difficult circumstances and official restrictions.

Natver paints a picture of his orphaned father, Narotam, as a 'naughty bugger' who was excluded from school because of too many pranks. He also subsequently got into some trouble for securing loans from two individuals but using the same property as security. To escape the consequences, he went to Bombay and 'wangled himself on board ship'. This was no ordinary migrant - he violated school norms and broke rules and acted illegally. Natver need not have told me all this but there is a hint of admiration for his father in the telling.

UD-M: So he actually ran away?

NP: He ran away.

UDM: So your dad was naughty?

NP: Ya well I mean you see he used to take lunch for his uncle on the farms and in the farms they used to have lunch break and lunch break can be very hot so he used to sit either on the well or on the shades of the big mango trees and he had heard of ... Johannesburg, the city of gold, the pavement of gold, and all sort of things and that all triggered him. That's what he told us. So he smuggled himself on board a ship and with the help of those chaps and what little money he had and he ended up in Lourenco Marques. These chaps, guys, had told him that you will find the trains going down to South Africa because the bananas used to come from Lourenco Marques and Brazza Congo those years. Those big crates of bananas I saw those myself and they used to come to South Africa.

So they told him what to do where about the station. He managed to find the station. Lucky for him he said he found some Indian workers too. They told him he must go as far as Johannesburg trains, Johannesburg Cape Town trains. So you know in those days there was no security check and things, stuff, was loaded. Guys walk away and somebody else comes and seals the doors. So he smuggled himself on board alone .... Any way he ended up in Johannesburg and Johannesburg he didn't know a word of English but he heard the word Cape Town so that same train was shunted to Cape Town and so he came up here ... The Cape Town early morning market ...[now] where the ... the Good Hope Centre [is], that used to be the early morning market and the banana siding was virtually near quarter way out towards Woodstock end so the trains used to come onto the siding and the bananas used to be loaded off into the auction room. The chaps used to come they used to open the door end ... and these chaps used to come and load. If the trains are late then the auction was held on the platform. He found himself there. Door opened - he walked out ...

The last sentence indicates the ease of arrival in Cape Town while the rest of the narrative is wordy indicating the length, details and complications of travel. Sometime later, his father secured legal documents to ensure his stay in Cape Town by drawing on the help of a white housewife whom he supplied vegetables to. Her husband had some connection to either the immigration office or police department and secured the necessary permit legalising his stay.

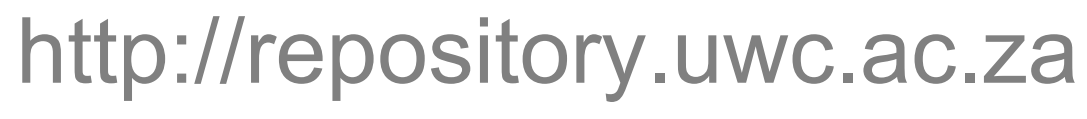


If his father's journey, some decades earlier, were of illegality and bravado, Natver's story of his own journey across the Indian Ocean from India to South Africa in 1939 is one of danger. In his telling of the two stories, mobility is marked by risk. It was war time, he was a six year old and the family travelled in the SS Tilawa from Bombay to Durban. He remembers this about the journey:

'No smoking. Just as soon as light ... becomes dark, they pull the cover. We used to come as deck passengers ... tarpaulins are pulled right over. No smoking and no talking loudly or anything because you never know when they sink you. And my brother was very sickly.' The words 'when they sink you' gain greater emphasis for Natver intersperses this story with that of the fate of the SS Tiklawa, a 'sister ship'. The latter does not come from his experience but from the circulation and discussion of this by people then and years down the line. In Natver's telling, the latter ship was sunk by the Japanese the same year. He adds local significance to this by mentioning that an Indian from the Strand died on that voyage and a Malayan from the Bo-Kaap survived the journey. The implication is there but for fortune it could have been his family.

Natver gets a few details wrong. It was in fact the SS Tilawa that was sunk and not in 1939 but in 1942. In his narrative, the dangers of travel of his own trip are emphasised by the sinking of the ship that very year, and not three years later. While Natver focuses on the local significance of the sinking of the ship, this was a tragedy of transnational importance. The sinking of the Tilawa features, for instance, in memoirs of East Africans journeying from Mumbai to Dar es Salaam (Kassum, 2007: 13) ${ }^{8}$ and in a website of commonwealth war deaths. 9 Over half a century after the event, the tragedy retains interest amongst Indians in Cape Town. The KKES, in fact, dedicated a page in their magazine to the death of 252 passengers and 28 crew (out of a total of 958 people) on board the Tilawa; Kaluskars who died or who survived are mentioned. 10 By linking the story of the two ships, Natver allows the historian to get a broader perspective of mobility in a time of war and tragedies that crossed national borders. This journey contrasts too with his subsequent everyday travels to school or to the market to buy fruit. Journeys by car could be ones for bonding with a father and for story-telling.

From travels, we shift the discussion to how Natver managed to remain in Simonstown which had been declared for whites and avoid relocation to Rylands, the area declared for Indians in 1957. Apartheid created a whirlwind of mobilities for black people but Natver secured a period of stability for him and his family. He firstly puts this down to advice he received to simply stay put and not buy property in Rylands and cites the liberal policy of the Simonstown Town Council. Then he tells a story that reveals his own agency. Sensing that his story may seem unbelievable, he stresses that 'It actually happened.' To remain on his site for business and residence purposes, he required a permit from the Group Areas Board. To secure this he relied on a National Party customer to use his influence. He then explains that his permit arrived at the office in Cape Town but 'someone was sitting on it there.' So he 
journeyed from Simonstown to the Cape Town city centre and spoke to the official at the office:

The bugger look at me. He said 'Look the permit is here but it is right at the bottom of the pile. You will have to come back tomorrow' but then ... he says 'Look you know what - my wife has bought a car. Can't you organise a car radio for me?'... I said 'I'm going to teach this bugger a lesson also.' I said 'Ok.' So he said 'Alright come tomorrow I'll have everything ready for you.' I went home. I took an old radio - those days you used to get the supersonic radios they were very shining and .... polished it up. And we used to have radio boxes put it in there. Thing wasn't working at all. [Natver laughs] Put it in there. Sealed the box. Made it nice and heavy. Give it to him. When he saw me coming in he smiled. I said 'You going to smile now we'll see who smiles later'. [Natver laughs] He gave me the permit and it was the end of the story.

When the official phoned him later, Natver feigned innocence insisting the radio was brand new. The mirth with which he tells this story is important, almost paralleled by his father's naughtiness as a child. The language 'Put it in there. Sealed the box. Made it nice and heavy' compares too with his telling of his father's arrival 'Door opened - he walked out'; short staccato sentences describing activities with significant outcomes. Both stories are about defeating officialdom and gaining an upper-hand despite odds. His father escaped a life of struggle in India and Natver escaped relocating to Rylands which would have had an adverse effect on his business. Both needed permits and both sought help to secure these. Towards the end of the interview, I ask Natver if I can use his name and his father's name. He replies: 'Let the people see what the people went through ... let them get the actual thing and they can see ... I have no objection you can write the names down. It's a fact.' Such a story could only be told in the post-colonial moment.

\section{A family trip to India}

Gunwant Jaga (b. 1942) and Bhadra Jaga (b. 1937) are owners of a successful shoe and shoe repairs store called Rocksole which is located in Wale Street in the historic Malay area, the Bo-Kaap. The shoe store was started by their grandfather, Jaga, who was the first to come to South Africa from India in the early 1900s. Their own father Kassen was born in India but joined his father when he was six years old. The brothers are thus third generation South Africans, and they have three sisters. The interview is mainly taken up by stories of them growing up in Cape Town, their schooling, their business and making lives in Rylands. However, they have significant things to say about India which they volunteer in the course of the interview (author's interview with Gunwant Jaga and Bhadra Jaga, 17 April 2010).

In Bhadra's telling, their grandfather's departure from the village of Bodali was 'to better his life from the small village. And you know they had guts. They had to come down to this not knowing the language or anything like that and trying to see if they can better their life ... not a dime in their pocket.' India is of some significance for the brothers for they tell me how their father later returned as a teenager to get married to their mother Shanti who was from the village of Amri. For some reason, they think it important to tell me that their 
grandfather's local travels from Cape Town to East London and Port Elizabeth was responsible for the identification of their mother in India as a suitable bride since friends in Port Elizabeth, related to Shanti, suggested her.

The interview proceeded to discussions about when the brothers were born, their schooling and when they joined their father in the business. They provide important empirical detail, but the brothers shape the interview themselves by volunteering information and by structuring the order of events. Bhadra suddenly tells me of how he and his three siblings accompanied their parents on a trip to India in 1945 when Bhadra was about eight and Gunwant three. This is important because it turns out it was the only such family trip in their lives. Bhadra contrasts the possessions they took with them to their anticipations about what little they might have when in India:

BJ: And that was something. I remember that. You know in those days we used to go by boat and I think we had to take a boat in Durban and we used to take big trunks like this - huge trunks like this - and not one. Now they going to India. It's as if there's nothing available in India. It's as if they had to take everything along and of course we were very small and of course we just did what they wanted us to do.

And we carried on and, of course, from here to Durban we stayed with Girdhar Dhanjee, which was my mother's mama [uncle]. We stayed there for couple days till we boarded the Karanja - must have been the Karanja.11 We boarded the Karanja and of course during those days it took 30 days to arrive. We used to go Lourenco Marques, Dar es Salaam, Mombassa, Mombassa to Mumbai. From Mumbai we again boarded the train to go to Navsari. Ok we got off at Navsari there was of course no modern transport. The bullock were waiting for us [Gunwant laughs] and everything was packed on it and we came to Bodali ...

Bhadra steers the conversation to his father's purchase of three properties in Wale Street prior to the departure to India. He could be anxious to get the sequence of events but the story is of major significance since it is about their business and their home in Cape Town. The main point of the dramatic auction story he tells is that his father purchased the properties for $£ 5000$ which was a substantial amount of money given that his father bought a car - an Opel Cadet - for £150. The juxtaposition of a tale of an Opel Cadet and travel by ship 'with huge trunks' with a bullock awaiting them on the other side also serves to emphasise the difference of their lives in South Africa, though they were not necessarily consciously and deliberately placed together. The two tales can be read together for they establish Kassen as a man of means and status in Cape Town. Yet Bodali is not only a place marked by material lack. It was, as Gunwant warmly embraces it, 'our gaam [village]' and there was 'a comfortable house'. It was also the birthplace of their sister Prabha - 'the only one in the family who was born in India'. 
I steer the brothers back to that trip to India:

UD-M: So I wanted to ask you when you went to India for the first time - that must have been your first time? So what can you remember about this?

BJ: When I arrived in India with the family members, you know, it must have been a helluva cultural shock because we don't know what we were in for. First and foremost though ... you got your bullock going through those dongas. It has, you know, big holes on both sides and just the wheels go through there. And, of course, that was from there onwards already we were just going with the flow.

We came to our house and, of course, in India you couldn't get butter bread and all those things. Those time they used to make rotla or rotli or whatever that was made and that is what we used to have at home. And, of course, I remember very well, mother had a bit of a tough time for the simple reason all the washing and everything had to be done. The cooking had to be done on the floor sitting on the floor. As far as the toileting is concerned that was a tragedy because (laughter) you know you just had to take your container and go and find a place ... we had a big field. This didn't carry on too long because Bapa [father] was a person with foresight and ... he did make some sort of facilities in the yard behind our house. The yard was big .... And of course our Gujarati school was ten minutes' walk from there ... Soon we also learnt to walk bare feet and in the hot sand and, of course, you start getting used to that too.

While they indicate their adaptability, and quick learning of the language, there is the hint above of their mother's hardships. Bhadra elaborates on his mother's difficulties as seen through his eyes:

... it was tough going for my mother in this respect that we used to have the ... well .. in the ...centre ... that water was to just wash and so on but drinking water she had to walk quite a distance. 20 minutes' walk from the house they had to walk ... and it was - I must say they were very strong in those days, in their times. Their way, they did what they had to ... Mother had one son born to her. Name was Prakash and he didn't live too long - just about two or three weeks ... and he ...passed on and then it wasn't long thereafter another sister to us was born and that was Prabha.

I wonder about Shanti's life in Cape Town and I thus shift the discussion and the chronology even further back, to when their mother first came to Cape Town, eight or so years before this return trip to India. While India meant infant mortality and arduous labour, the story of their mother's life in Cape Town is a story of progress, of adaptability and acquiring skills, 'a big story'. This is in response to a very simple question posed by me:

UD-M: Did your mum have many Gujarati friends?

GJ: O that's a big story . As far as her coming to Cape Town was you know not knowing anybody. But because we were in the Bo-Kaap area we were surrounded with Indians. We

\section{http://repository.uwc.ac.za}


had about eight family members ... with the result those were all Indian ladies. The only lady that knew quite a bit was ...

Bhagatsingh's mother, Vajia Kaki ... She knew a little bit more. And then my mother learned how to cook because she was very young here [sixteen] and when she had to learn about cooking and things like that and speak Afrikaans or doing shopping and doing sewing hand sewing and things like that they used to be friends together. They used to walk to District Six and ...she picked up Afrikaans very nicely. My dad, like my brother says, he was always one ahead and he sent her to school and he got a teacher to teach Ma [mother] and to sign documents, to sign S K Jaga, and things like that. So she actually read and my father would be forceful to do that so she was quite on the ball that way.

BJ: Dad in this business where he was running at 59 Wale Street ... the frontage used to be so wide but the passage there was a long passage here and that's where he used to have all his up to date machinery and he used to have a big staff working there and mother used to work, also come to the shop and she used to write down tickets. She used to take customers' instructions.

While Natver's tale is a masculinist story of bravado, the brothers' narrative allows for a reading of a woman's mobility albeit through male eyes. One should note too that behind Shanti is a husband who was also 'forceful' in fostering his wife's development.

The narrative then shifts to the advent of the Group Areas Act and its influence on the family. The family, like Natver Patel, had to secure permits to run the business but for residential purposes they moved to Rylands. Their father had, in fact, been one of the major purchasers of property in Rylands, and the brothers, in addition to running the shop, began to develop these properties and lease them to Indians in search of accommodation. While there are several hints of victimhood at the hands of officialdom (having to relocate to Rylands for residence thus making a greater travelling distance from home and work, and having to supply Group Areas Board officials with shoes for their families so that they could continue to get their business permits renewed), the story of the brothers lives is one of capital accumulation and initiative in the newly developing group area for Indians. There is also an immersion in the religious life of the Mochi community (the shoemaker caste among the Gujarati Hindus) which revolved around building a temple in Rylands (see DhupeliaMesthrie, 2014: 359-360, 363). The brothers no longer live in Rylands - Bhadra subsequently returned to the Bo-Kaap and Gunwant lives in an apartment in a building owned by him with a stunning view of the Atlantic seaboard and the newly built Green Point stadium built for the World Cup Soccer in 2010. There is another mobility in this story - that of class and upward socio-economic status.

\section{'I'm a different person from the others'}

I had known Damyanti Patel (b. 1954) for several years as a teacher at the Gandhi Memorial School in Rylands and as a food caterer. During one such trip to pick up food, she told me she was once educated in India and I was interested in hearing more (author's interview with Damyanti Patel, 20 June 2009). She was born in Johannesburg in 
the suburb of Malvern in 1954 where her father had a small grocery shop. Both her parents had originally come from villages close to Navsari (in Gujarat), her paternal grandfather being the first to come to South Africa. She was her parents' first-born. Her life took a dramatic turn in 1959 when, aged five, she was separated from her siblings and parents. Her father enrolled her at a boarding school in Baroda in India. The school was a Gurukul called the Arya Kanya Mahavidyalaya and had a student population of 3500 . Boarders slept in dormitories with 80 to 90 persons per room. Students came from across the globe - she mentions Kampala and Nairobi in particular - and from across India.

Damyanti explains the idea of a Gurukul to me and in her detailing of activities she reveals a place of ordered time.

Gurukuls are all different. They're based on ancient rishis ancient ways ... bath in the cold water ... Only if it's very very cold you were allowed to wear a jacket. You were not allowed to wear jerseys at all ... And then they ring the bell and according the bell then they ring, you must get up you must do your work, homework, you must come out of the class from the room and then start your activities. Once you leave your room you not allowed to go back in there ...Till nine o clock at night ... Like five o clock we get up then we pray. After we pray we go and have our bath. We bath and we wash our clothes and then after that we come back then we must do our studies. We must study a little while for an hour or so. After that we must go and do exercises. After exercises is done then we must go and do sandhya havan [evening prayers] ... full havan every day ... .And that is finished then we go and have our nasto nasta breakfast ...

In a Gurukul you live simple ... you not allowed to wear long sleeve clothes or anything. Just short sleeve shirts and shorts, that's all. No earring no nothing no jewellery ...

Inspired by Gandhi's teachings of frugalness, they were issued with two pencils which had to last for six months. 'So we had to be careful how to use the pencil.' On Saturdays, the routine relaxed and they had half a day to themselves. Sundays were devoted to lectures on life by various spiritual teachers.

For ten years, Damyanti saw her father but twice in India and her mother not at all. Letters are a crucial means of bridging spatial divides. Yet, she was allowed to write home just once a month. 'They used to read our letters. We not allowed to write anything that we don't like this school. It was so strict ... we have to write we like it very much ... .' During holidays, twice a year, her mother's uncle would take her to his village in Kachiawadi near Navsari. There she bonded with the family. 'I used to cry a lot ... whenever I come back home and then it's going time I used to cry but once they leave I am alright.' Home became her uncle's home. South Africa had receded.

I am quite stunned by this image of frugality and the extended separation of a child from her parents. Her account of tears hints at the difficulties she experienced. In her response to a question as to why her father sent her away, I am struck by the fact that there is no tone of 
resentment or complaint. Her father simply believed in this style of life and he was living an arduous and precarious existence as a trader in the apartheid era. 'My father had a tough time ... you see ... because there was a group area and he had to move around from one place to other place. So also I think that is the reason. I was the eldest one so he had to leave me in India so when he comes here then he can at least do what he wants to do... They struggled a lot.' The contrast between the hurly burly lifestyle of an Indian in Johannesburg, trading on other people's licences and on the move constantly, contrasts with the serenity of the Gurukul. Apartheid oversaw disorder and forced mobility; the Gurukul regulated order and confined mobility.

Apartheid soon came to intervene in this orderliness. Each year she had to renew her permit to remain out of South Africa. In her final year at the school which would have been the equivalent of matriculation, her father, preoccupied with his mother's illness in India, forgot to send her papers in time. Not one to dwell on her own feelings of distress, she nonetheless tells me 'I was heart sore'. With half her examinations completed, and with a future set on learning Ayurveda, she was forced to return home. The journey home was a challenge - she knew no English and could not communicate with the air hostesses on the plane. There was happiness at a reunion with parents and five other siblings (including a two month old baby sister) but English was a major challenge. 'I said no now if I can't speak I'm going away to India back and then I don't want to come back.'

The sixteen year old was sent to school as her father insisted she learn to read and write English. She was placed in Standard 3 with children much younger than her by at least five or six years. She picked up the language quickly, coming first. At home her sister helped her speak and standing in her father's shop she learnt some Afrikaans and Zulu. After two years, she left school and secured a position as a typist and punch card operator. Like Shanti whose marriage involved mobility across continents, Damyanti's marriage involved relocation albeit across provincial borders within South Africa. Her marriage was arranged with a printer from Cape Town and in 1972 she came to the slowly developing Rylands. Children were born in 1974, 1978 and 1981. Damyanti's India education came to good use as she became a Gujarati teacher. Once a week, she commutes to Worcester, a rural town outside of Cape Town, to teach Gujarati to the Indian children there. She observes: 'Now the children come to school they don't know one word of Gujarati - you tell them to stand up sit up beso ubha thao they don't know. They look at your face "Ben, what did you say?" She is probably the best person to understand these difficulties of communication.

I am interested in what this entire experience of being in India and away from home meant to her. I ask her if her father did the right thing. Her response is, 'He felt he did good ... I also feel like my personality and that is different. I feel I feel like I'm a different person from the others ... in a better way.' Even with her siblings, 'I still feel sometimes I am the outsider.' She was more at one with her relatives in India. Memories of the school routine survive and some habits remain. She wakes up at 4am every day and meditates, and in the evening she meditates again. She continues to bathe in cold water except on severely cold days. Thus, she reproduces in Rylands in a small way her memories of life at the Arya Kanya Mahavidyalaya. 


\section{Conclusion}

This article started out with a discussion of transnational links amongst Indians in Cape Town and then shifted to a detailed study of interviews with four individuals to highlight memories of transnational journeys and journeys within the nation. The goal was not to reproduce empirical data, but to explore how the narratives are produced in the dialogue and what emerges voluntarily and the meanings that may be read from how interviewees responded. The narratives render India variously as a place of poverty, illness and death from which one has to escape; a place for learning and spirituality; a place where extended family continues to exist; and a place where there are homes. Permits and documents of travel feature - they often acted to close the door to continued residence in India or acted as barriers to entering South Africa. Journeys by ship and plane are recollected - they indicate, variously, dangers, bravado, adventure, and difficulties.

Vertovec has argued that 'transnationalism and identity are concepts that inherently call for juxtaposition' (Vertovec, 2001: 573). In these narratives of second and third generation South Africans we see how they felt their difference in India but also the resilience of youth. Too long a stay in India produced difference with other South Africans, even within the family. The narratives are gendered - from masculinist tales of beating systems to accounts of female adaptation and growth. Language adaptation features in these stories of transnational movement. Memories, as in the case of one interviewee, are crucially produced in local journeys by car. Memories produced against the backdrop of the 150 year commemorations, stress the South Africanness of the interviewees but point to the importance of roots and heritage - what was left behind in India and how homes were made, despite some difficult circumstances in South Africa.

This article has argued for the importance of examining narratives of local journeys alongside transnational journeys. But it also stresses that attention be paid to when there is no movement. A father's tale of crossing the ocean illegally has to be read alongside his son's determination to beat the Group Areas Act and avoid movement. A daughter's confinement in a Gurukul has to be read alongside her father's constant movement because of apartheid laws. In the post-colonial moment it is not yet possible to shrug off the weight of the apartheid past and the Group Areas Act features prominently. Upward socio-economic mobility within the nation can cast meanings on transnational journeys between India and South Africa.

This article would like to end with a suggestion of how transnational memories could be approached differently. The methodology here has been to make as subjects the interviewees who live in one locality - Cape Town, South Africa - and their memories. Transnational research needs to be, as Ulf Hannerz, points out 'multilocal but also translocal' (quoted in Vertovec, 1999: 457). The subject matter could be different. It could, for instance, be the sinking of the SS Tilawa which binds together East Africans, South Africans, Indians, and the British in the range of citizens who found themselves on that illfated ship. Natver's memory as well as East African memories, as this article suggests, points to it being a transnational event of some significance. The Arya Kanya 
Mahavidyalaya could be the subject about which memories could be drawn from those who attended from South Africa and East Africa, other parts of the world and other parts of India. In these two possibilities, the site becomes the centre around which memories may be gathered across nations. It would also be interesting to know how Dawood Amien is remembered in Kalusta by those who attend the school he built. Homes and villages in India feature in the memories of second and third generation South Africans - the reflections of those who are visited upon and who receive the South Africans need to also form part of this telling. In such a broad telling one would then be better able to evaluate the place of the local and national in the telling of the transnational.

\section{Acknowledgements}

The research for this article was supported by the National Research Foundation of South Africa but reflects the views solely of the author. I would like to thank Leslie Witz for pointing me to some transnational memory work in South Africa. I am grateful to all interviewees who shared their stories and consented to the use of their names.

\section{Declaration of Conflicting Interests}

The author(s) declared no potential conflicts of interest with respect to the research, authorship, and/or publication of this article.

\section{Funding}

The author(s) received no financial support for the research, authorship, and/or publication of this article.

\section{Notes}

1. 8o Years and Beyond: Kalusta Karijker Educational Society, 16 October 2010.

2. See letter to the editor by Ashraf Joolay in Cape Times, 11 February 2010.

3. See article by Ashraf Kagee in Cape Times, 1 February 2010.

4. Based on information from Naresh Chauhan, undated.

5. See video recording mg.co.za/multimedia/2010-12-20-from-sa-to-india-onemansjourney

6. See www.habsani.co.za/?page-id=113, 'Notes of Habsani Royals' visit to India in 2011'.

7. The list of auto/biographical productions is too vast to reproduce but the lives of Thabo Mbeki, Oliver Tambo, Aziz Pahad, Mac Maharaj, Natoo Babenia, Yusuf Dadoo and Goonam Naidoo are relevant here.

8. He also gets dates mixed up. Kassum travelled in August 1942 and the ship was torpedoed in November but in his telling it was on the return journey of the Tilawa after he got off that the ship met its fate.

9. See www.cwgs.org/find-war-dead.aspx?page=1\&sort=name\&order $=$ asc

10. 8o Years and Beyond: Kalusta Karijker Educational Society, 16 October 2010, 29.

11. It was probably not the Karanja as the ship was hit by a torpedo in 1942 and was replaced by a new Karanja only in 1948 . 


\section{References}

Bickford-Smith V, Field S and Glaser C (2001) The Western Cape Oral History Project: the 1990s. African Studies 60(1): 5-21.

de Cesari C and Rigney E (2014) Introduction. In: de Cesari C and Rigney A (eds) Transnational Memory: Circulation, Articulation, Scales. Berlin, Germany: De Gruyter, pp. 1-16.

Directorate of Strategic Information (2003) A Population Profile of the City of Cape Town: Socio-Economic Information from the 2001 Census. Cape Town, South Africa: City of Cape Town.

Dhupelia-Mesthrie U (2012) Cultural crossings from Africa to India: select travel narratives of Indian South Africans from Durban and Cape Town, 1940s to 1990s. South African Historical Journal 64(2): 295- 312.

Dhupelia-Mesthrie U (2014) Speaking about Rylands: a Cape Flats history, 1960s to 1980 s. Social Dynamics, 40(2): 353-370.

Erll A (2011) Travelling memory. Parallax 17(4): 4-18.

Field S (ed.) (2001) Lost Communities, Living Memories: Remembering Forced Removals in Cape Town. Cape Town, South Africa: David Philip.

Field S (2012) Oral History, Community, and Displacement: Imagining Memories in PostApartheid South Africa. New York, NY: Palgrave MacMillan.

Field S, Meyer R and Swanson F (eds) (2007) Imagining the City: Memories and Cultures in Cape Town. Cape Town, South Africa: HSRC Press.

Gunn S (ed.) (2011) Torn Apart: Thirteen Refugees Retell their Stories. Cape Town, South Africa: Human Rights Media Centre.

Gupta P, Hofmeyr I and Pearson M (eds) (2010) Eyes Across the Water: Navigating the Indian Ocean. Pretoria, South Africa: Unisa Press.

Hansen TB (2012) Melancholia of Freedom: Social Life in and Indian Township in South Africa. Princeton, NJ: Princeton University Press.

Hiralal K (2013) "Daughters of Gujarat in the diaspora": Immigrant women, identity and agency in Natal. Journal for Contemporary History 38(1): 1-21.

Hofmeyr I and Williams M (eds) (2011) South Africa and India: Shaping the Global South. Johannesburg, South Africa: Wits University Press.

Julius C (2008) 'Digging deeper than the eye approves': oral histories and their use in the Digging Deeper Exhibition of the District Six Museum. Kronos 34(1): 106-138.

Kassum AN (2007) Africa's Winds of Change: Memoirs of an International Traveller. London, UK: L.B. Tauris \& Co Ltd.

Layne V and Rassool C (2001) Memory rooms: oral history in the District Six Museum. In Rassool C and Prosalendis S (eds) Recalling Community in Cape Town: Creating and Curating the District Six Museum. Cape Town, South Africa: District Six Museum, pp.146-153.

Likuwa K (2012) Voices from the Kavango: a study of the contract labour system in Nambia, 1925-1972. PhD Thesis, University of the Western Cape.

Lusaka M (2015) Conserving spaces of memory and heritage: the complexities, challenges and politics of the Stone Wall Project in Bluestone Quarry at Robben Island. MA Thesis, University of the Western Cape. 
Maharaj B (2012) Commemoration, celebration or commiseration? 150th anniversary of the indentured Indians. In: Patel $\mathrm{C}$ and Uys $\mathrm{T}$ (eds) Contemporary India and South Africa: Legacies, Identities, Dilemmas. London, UK: Routledge, pp.77-95.

Marschall M (2014) 'Homesick tourism': memory, identity and (be)longing. Current issues in Tourism 18(9): 876-892.

Masada I (2007) Where is home? Transnational migration and identity amongst Nigerians in Cape Town. In: Field S, Meyer R and Swanson F (eds) Imagining the City: Memories and Cultures in Cape Town. Cape Town, South Africa: HSRC Press, pp.93-114.

Mesthrie R (2011) Public lecture series on 150 years of Indian history in South Africa. Social Dynamics 37(3): 436-438.

Minkley G and Rassool C (1998) Orality, memory and social history in South Africa. In: Nuttall S and Coetzee C (eds) Negotiating the Past. Cape Town, South Africa: Oxford University Press, pp. 89-99. Murray N and Witz L (2014) Hostels Homes Museum: Memorialisng Migrant Labour Pasts in Lwandle, South Africa. Cape Town, South Africa: UCT Press.

O'Connell S (2012) Tonal landscapes: remembering the interiority of lives of Apartheid through the family album of the oppressed. PhD Thesis, University of Cape Town.

Oka RC and Kusimba CM (2008) Siddi as mercenary or as African success story. In: Hawley JC (ed.) India in Africa, Africa in India: Indian Ocean Cosmopolitanisms. Bloomington, IN: Indiana University Press, pp.203-230.

Rogaly B (2015) Disrupting migration stories: reading life histories through the lens of mobility and fixity. Environment and Planning: Society and Space 33(5): 528-544.

Rothberg M (2014) Multidirectional memory in migratory settings: the case of postholocaust Germany. In: de Cesari C and Rigney A (eds) Transnational Memory: Circulation, Articulation, Scales. Berlin, Germany: De Gruyter, pp.123-145.

South African Democracy Education Trust (2015) The Road to Democracy - South Africans Telling Their Stories. Volume 1: 1950-1970. Cape Town: HSRC Press.

Smit R and Ragunanan P (2015) Transnational forced migration and negotiating emotional well-being: the case of women refugees in South Africa. Social Dynamics 41(1): 184203.

Statistics South Africa, Census (2011) Statistics South Africa: Census 2011-Cape Town Profile. Cape Town, South Africa: SDI and GIS Department.

Vertovec S (1999) Conceiving and researching transnationalism. Ethnic and Racial Studies 22(2): 447-462. Vertovec S (2001) Transnationalism and identity. Journal of Ethnic and Migration Studies 27(4): 573-582.

\section{Author biography}

Uma Dhupelia-Mesthrie is a senior professor in the History Department at the University of the Western Cape and Deputy Dean of Research in the Faculty of Arts. Her central research interest is India-South Africa connected histories and in recent years she has published a series of essays on Indians in Cape Town. She is author/editor of Cane Fields to Freedom: A Chronicle of Indian South African Life (Kwela Books, 2000); Sita: The Memoirs of Sita Gandhi (Durban Local History Museum, Pretoria, 2003); and Gandhi's Prisoner?

The Life of Gandhi's son Manilal (Kwela Books, 2004). 